\title{
HEMATOLOGICAL STANDARDS, HORMONAL INDEXES AND GONADAL MORPHOLOGY OF ROADSIDE HAWKS (RUPORNIS MAGNIROSTRIS)
}

\author{
Padrão hematológico, índices hormonais e morfologia gonadal de gaviões-carijó \\ (Rupornis magnirostris)
}

Ricardo Romão Guerra1', Glenison F. Dias, Maria G.S. Bernadino, Nailson A.N. Junior, Monalisa F.V.F. Guerra, Fabiana Satake.

\section{Universidade Federal da Paraíba}

${ }^{1}$ Corresponding author: ricardo@cca.ufpb.br

\begin{abstract}
Efforts to conserve birds of prey have been increasing over the past three decades, highlighting breeding programs in captivity and zoos, scientific research, environmental education, rehabilitation and reintroduction. In order to generate subsidies for such actions, blood samples and gonads were collected from 24 roadside hawks to determine the hematological and hormonal indexes and gonadal morphology. Routine techniques for hematological, histological and chemiluminescence analyses were used to determine hematology, gonadal morphology and hormone levels, respectively. Hematological values of PCV, erythrocytes and lymphocytes differed between the birds recently-arrived in captivity and the birds with at least one year of captivity, a difference associated to the higher level of stress of the newly arrived animals due to the recent exposure to captivity conditions. T3 was significantly different between females and males, and T3 and T4 were higher in animals during feather moulting. The gonadal morphology was similar to that of other birds, however, persistence of the right ovary was observed in $66 \%$ of the cases, and other characteristics indicative of a seasonal reproductive cycle in the Brazilian Northeast. The data collected serve as subsidies for the clinical care of this species, besides providing a better understanding of the reproduction of birds of prey, and assisting in the preservation.
\end{abstract}

Keywords: endocrinology; histology; blood parameters; raptors

RESUMO: Os esforços para a conservação das aves de rapina vêm aumentando nas últimas três décadas, destacando-se programas de reprodução em cativeiro e zoológicos, pesquisas científicas, educação ambiental, reabilitação e reintrodução. Para gerar subsídios para tais ações foram coletadas amostras de sangue e gônadas de 24 gaviões-carijó para determinação dos índices hematológicos, hormonais e morfologia gonadal. Foram utilizadas as técnicas de rotina para as análises hematológicas, histológicas, e de quioluminecência, para a determinação da hematologia, da morfologia gonadal e dos níveis hormonais, respectivamente. Os valores hematológicos de VG, eritrócitos e linfócitos diferiram entre as aves recém-chegadas ao cativeiro e aves com no mínimo um ano de cativeiro, diferença associada ao maior estresse dos animais recém-chegados devido à recente exposição às condições de cativeiro. T3 apresentou diferença significativa entre fêmeas e machos, e T3 e T4 foram mais altos em animais em muda de penas. A morfologia gonadal foi semelhante às demais aves, entretanto, observou-se persistência de ovário direito em $66 \%$ dos casos e outras características indicativas de um ciclo reprodutivo sazonal no Nordeste brasileiro. Os dados coletados servem como subsídios para atendimentos clínicos dessa espécie, além de proporcionar 
uma melhor compreensão da reprodução das aves de rapina auxiliando na sua preservação.

Palavras-chave - endocrinologia; histologia; parâmetros sanguíneos; rapinantes 


\section{INTRODUCTION}

The Roadside Hawk (Rupornismagnirostris, Gmelin, 1788) is a bird of prey that occurs from Mexico to Argentina, and is found in all Brazilian territory (Fergunson-Lees and Christie 2001). It belongs to the Accipitriformes genus and the Accipitridae family (CBRO, 2011), has an average size of 31 to $40 \mathrm{~cm}$, weighs from 250 to 300 grams according to sex and subspecies, and has a dark back and striated chest. Its tail has 4 to 5 light strips contrasting with dark gray or black strips (Sick, 1997). Molecular studies show that this species is the most primitive of all Buteos, which led to its classification into a genus of its own: Rupornis (Lerner et al., 2008). Its name comes from the Greek: rhupos = dirty, dirt; and ornis = bird; and from the Latin: magnus = big; and rostris = beak; thus, being the dirty hawk with a big beak or the big-beaked falcon (Latham, 1781). These birds inhabit open fields, edges of forests, woods, banks of rivers, lakes and urbanized areas (Sick, 1997), and they are adapted to anthropic action, so they are easily observed in urban centers, where it is possible to observe their reproduction (Santos and Rosado, 2009).

They are among the birds of prey most frequently taken to Triage Centers in several regions of Brazil, in many cases requiring clinical analysis and rehabilitation before being released. However, it is necessary to know the standard hematological values in order to establish criteria for release (Black et al., 2011) and assist in clinical diagnoses. So far, these standards and criteria are non-existent, even because the stress caused by captivity can change some of the hematological parameters (Davison and Flack, 1981; Post et al., 2003; Speer and Kass, 1995; Rodler et al., 2015).
Another gap in knowledge of birds of prey is related to the hormonal parameters related to stress and reproduction. The reproductive cycle of animals is controlled by several factors that affect the secretion of sex hormones and the presence of specific receptors for these hormones (Madekurozma et al., 2002). The cyclic variation of testosterone has already been described in some species such as in the Chinese quail and in the Hylophylaxnaevioide; in these species it is possible to observe changes in the reproductive system, such as the presence of spermatozoa in the seminiferous tubule and increased height of the seminiferous epithelium (Amoroso et al., 2008; Baraldi-Artoni et al., 2007). However, there is lack of information in literature about testicular morphology of birds of prey, including the roadside hawk.

In the females, an important difference compared to mammals is the development of only one of the ovaries in most birds, the left ovary (Parizzi et al., 2007). Regarding seasonality, in some females, it is possible to observe a positive correlation between the increase of the photoperiod and the thickness of the wall of the follicle and increase in the amount of mature follicles (Dixit and Singh 2013). There are only two studies available related to seasonal patterns of hormone secretion in birds of prey, an article involving bald eagles (Haliaaetus leucocephalus) in captivity (Bercovitz et al., 1982), and one with free male American Kestrel (Falcos parveverius) (Pereira et al., 2010). There are no such studies on the roadside hawk, neither on the morphology of the gonads of these species.

Since there is a difficulty to collect blood samples in birds, and in the scarcity of reference values, the use of techniques with small volumes of samples, and the laboratory diagnosis in birds, including falconiformes, are impaired. There is still an aggravating 
factor: most of the scarce data available originate from studies conducted outside of Brazil, where most of the time the climates and managements differ from those in our environment. Therefore, insufficient clinical reference data and complementary tests limit the diagnosis of metabolic and/or nutritional diseases in captive species (Thralli et al., 2012). Thus, knowledge of the hematological alterations of captive birds can serve as subsidies for the study of the responses of animals in the wild within a certain pathogen or challenge, as well as facilitate the diagnosis of diseases (Carvalho et al., 2013).

Considering the above, the present study aims to standardize the hematological values, hormonal indexes and morphology of the gonads of the roadside hawk, in order to generate subsidies for the care of this species and for projects of reproduction and reintroduction into nature.

\section{MATERIAL AND METHODS}

For the hematological study, blood samples were collected from 12 adult individuals $(6$ females and 6 males) of the Rupornis magnirostis species from the Zoobotanical Park Arruda Câmara, João Pessoa, Paraíba. The birds were physically contained, immobilized, and a falconry hood was used to lessen their stress. Blood collection was performed by puncturing the cephalic artery. Blood samples were at most $1 \%$ of the live weight (Carvalho et al., 2013; Almosny et al., 2007). EDTA was used as an anticoagulant. Routine techniques were used for the hematological parameters: globular volume, erythrocytes, hemoglobin, mean corpuscular volume (MCV), mean corpuscular hemoglobin concentration $(\mathrm{MCHC})$, total plasma protein (TPP), fibrinogen, leukogram, monocytes, heterophils, lymphocytes, eosinophils and basophils (Thralli et al., 2012). For the hematological analyses, the zoo animals were divided into two groups, the first composed of recently-arrived birds (3 months on average) that were destined for release (6 specimens), and the second group was composed of birds that were already part of the zoo for more than a year ( 6 specimens).

For the hormonal analysis, a another 12 specimens were used, 6 females and 6 males, destined to the Center for Rehabilitation of Wild Birds (Centro de Reabilitação de Aves Silvestres - CeRAS), of the Zoological Park Arruda Câmara, according to the authorization for scientific activity, number 46535-1 of the SISBio-IBAMA and Certificate of the Ethics Committee on the Use of Animals of the Federal University of Paraíba (Certidão da Comissão de Ética no Uso de Animais da Universidade Federal da Paraíba CEUA-UFPB) number 172/2015. For the experiment, the birds were anesthetized with ketamine (20 mg / kg-1) and xylazine (1 mg / kg-1) and blood was collected by intracardiac puncture without the presence of anticoagulant to obtain serum, which was preserved by freezing. After the collection of the samples, the animals were euthanized through the use of intracameral lidocaine. The hormonal analysis of thyroid stimulating hormone (TSH), triiodothyronine (T3), thyroxine (T4), follicle stimulating hormone (FSH), luteinizing hormone (LH), estradiol (E2), progesterone and testosterone was performed by the chemiluminescence method.

After euthanasia, these animals were dissected for analysis of the topography of the sex organs and their morphology. The organs were collected and submitted to standard histological processing (Martinez-Silvestre et al., 2011; Ramos et al, 2011). For the histological analysis, the tissues were 
cut to a thickness of $5 \mu \mathrm{m}$ and stained with hematoxylin and eosin for the observation of the structures and to obtain photomicrographs through the Moticlmage Plus 2.0 program of the Moticam 2500 camera coupled to an Olympus BX-60 microscope.

For the statistical analysis, the Bioestat 5.3 program was used to compare the values of the groups. The $T$ and Mann-Whitney tests were used, to analyze parameters with normal distribution and those without normal distribution, respectively.

\section{RESULTS}

The results for the hematological parameters and hormonal indexes are found on Table 1.

Table 1 - Weight, haematological standards and hormonal indexes of captive Roadside Hawks (Rupornis magnirostris) in the Zoobotanical Park Arruda Câmara, João Pessoa, PB, Brazil.

\begin{tabular}{|c|c|c|}
\hline Parameters & Average & Default error \\
\hline \multirow[t]{2}{*}{ Weight } & $267.68 \pm 30.48$ & 8.80 \\
\hline & Erythrogram & \\
\hline$P C V\left(L L^{-1}\right)$ & $0.36 \pm 0.04$ & 0.01 \\
\hline $\operatorname{RBC}\left(\times 10^{12} \mathrm{~L}^{-1}\right)$ & $1.79 \pm 0.26$ & 0.07 \\
\hline $\mathrm{Hb}\left(\mathrm{g} \mathrm{L}^{-1}\right)$ & $8.09 \pm 0.78$ & 0.22 \\
\hline $\operatorname{MCV}(f L)$ & $199.55 \pm 13.01$ & 3.61 \\
\hline $\mathrm{MCHC}(\%)$ & $22.87 \pm 1.96$ & 0.54 \\
\hline $\mathrm{TP}\left(\mathrm{g} \mathrm{L}^{-1}\right)$ & $5.15 \pm 1.19$ & 0.33 \\
\hline \multirow[t]{2}{*}{ Fibrinogen $\left(\mathrm{g} \mathrm{L}^{-1}\right)$} & $0.12 \pm 0.11$ & 0.03 \\
\hline & Leukogram & \\
\hline WBC $\left(\times 10^{9} \mathrm{~L}^{-1}\right)$ & $13.28 \pm 5.45$ & 1.51 \\
\hline Monocytes (\%) & $10.00 \pm 7.08$ & 1.96 \\
\hline Monocytes $\left(\times 10^{9} \mathrm{~L}^{-1}\right)$ & $1.21 \pm 1.05$ & 0.29 \\
\hline Heterophiles (\%) & $57.79 \pm 15.53$ & 4.31 \\
\hline Heterophiles $\left(x 10^{9} \mathrm{~L}^{-1}\right)$ & $7.52 \pm 5.22$ & 1.45 \\
\hline Lymphocytes (\%) & $5.67 \pm 3.60$ & 1.00 \\
\hline Lymphocytes $\left(x 10^{9} \mathrm{~L}^{-1}\right)$ & $0.73 \pm 0.64$ & 0.18 \\
\hline Eosinophils (\%) & $14.2 \pm 8.82$ & 2.45 \\
\hline Eosinophils $\left(x 10^{9} \mathrm{~L}^{-1}\right)$ & $1.43 \pm 1.38$ & 0.38 \\
\hline Basophils (\%) & $1.35 \pm 1.78$ & 0.49 \\
\hline Basophils $\left(x 10^{9} \mathrm{~L}^{-1}\right)$ & $0.15 \pm 0.15$ & 0.04 \\
\hline
\end{tabular}

\begin{tabular}{lcc}
\hline \multicolumn{3}{c}{ Hormonal Indexes } \\
\hline TSH $\left(\mathrm{uUl} \mathrm{mL}^{-1}\right)$ & $0.28 \pm 0.02$ & 0.01 \\
T3 $\left(\mathrm{ng} \mathrm{dL}^{-1}\right)$ & $178.42 \pm 129.37$ & 37.35 \\
T4 $\left(\mathrm{mcg} \mathrm{dL}^{-1}\right)$ & $1.46 \pm 1.04$ & 0.30 \\
FSH $\left(\mathrm{mUl} \mathrm{mL}^{-1}\right)$ & $0.33 \pm 0.36$ & 0.10 \\
LH $\left(\mathrm{mUI} \mathrm{mL}^{-1}\right)$ & $0.29 \pm 0.57$ & 0.16 \\
E2 $\left(\mathrm{pg} \mathrm{mL}^{-1}\right)$ & $37.33 \pm 21.49$ & 6.20 \\
Progesterone $\left(\mathrm{ng} \mathrm{mL}^{-1}\right)$ & $1.48 \pm 0.92$ & 0.27 \\
Testoterone $\left(\mathrm{ng} \mathrm{dL}^{-1}\right)$ & $10.35 \pm 1.21$ & 0.35 \\
\hline
\end{tabular}

PCV: Packed cell volume. RBC: Red Blood Cell. Hb: Hemoglobin concentration. MCV: Mean corpuscular volume. MCHC: Mean corpuscular hemoglobin concentration. TP: Total Protein. WBC: White Blood Cell. TSH: Thyroid stimulating hormone. T3: Triiodothyronine. T4: thyroxine. FSH: Follicle Stimulating Hormone. LH: Luteinizing Hormone. E2: Estradiol.

It is possible to find different values in the hematological parameters of groups 1 and 2 (Table 2). For FCV and erythrocytes, the values are higher in the group formed by the recently arrived birds at the zoo (3 months on average), and for lymphocytes, the values are higher in group 2 , of the birds that had been in the zoo for more than one year.

Table 2 - Comparison of haematological parameters of the two groups of Roadside Hawk (Rupornis magnirostris), group 1: with newly arrived birds (up to 3 months) to the zoo and group 2: with birds of the Zoological Park Arruda Câmara, more than a year.

\begin{tabular}{|c|c|c|c|}
\hline & Geral & Group 1 & Group 2 \\
\hline Weight (g) & $267.00 \pm 30.00$ & $256.00 \pm 18.00^{\mathrm{a}}$ & $283.00 \pm 38.00^{\mathrm{a}}$ \\
\hline $\operatorname{PCV}\left(\mathrm{L} \mathrm{L}^{-1}\right)$ & $0.36 \pm 0.04$ & $0.38 \pm 0.04^{\mathrm{a}}$ & $0.33 \pm 0.020^{\mathrm{b}}$ \\
\hline $\operatorname{RBC}\left(x 10^{12} \mathrm{~L}^{-1}\right)$ & $1.77 \pm 0.26$ & $1.90 \pm 0.29^{\mathrm{a}}$ & $1.63 \pm 0.79^{\mathrm{b}}$ \\
\hline $\mathrm{Hb}\left(\mathrm{g} \mathrm{L}^{-1}\right)$ & $8.09 \pm 0.78$ & $8.30 \pm 0.85^{\mathrm{a}}$ & $7.84 \pm 0.68^{\mathrm{a}}$ \\
\hline MCV (fL) & $199.55 \pm 8.78$ & $194.49 \pm 15.82^{\mathrm{a}}$ & $204.61 \pm 7.77^{\mathrm{a}}$ \\
\hline $\mathrm{MCHC}(\%)$ & $22.87 \pm 1.96$ & $21.99 \pm 1.49^{\mathrm{a}}$ & $23.93 \pm 2.08^{\mathrm{a}}$ \\
\hline $\mathrm{TP}\left(\mathrm{g} \mathrm{L}^{-1}\right)$ & $5.15 \pm 1.19$ & $5.51 \pm 1.37^{\mathrm{a}}$ & $4.72 \pm 0.81^{\mathrm{a}}$ \\
\hline Fibrinogen $\left(\mathrm{g} \mathrm{L}^{-1}\right)$ & $0.12 \pm 0.11$ & $0.14 \pm 0.13^{\mathrm{a}}$ & $0.10 \pm 0.10^{\mathrm{a}}$ \\
\hline $\begin{array}{l}\text { Leucograma } \\
\left(\times 10^{9} \mathrm{~L}^{-1}\right)\end{array}$ & $13.28 \pm 5.45$ & $13.06 \pm 6.62^{\mathrm{a}}$ & $13.54 \pm 4.32^{\mathrm{a}}$ \\
\hline Monocytes (\%) & $10.81 \pm 7.38$ & $10.35 \pm 6.58^{\mathrm{a}}$ & $11.33 \pm 8.82^{\mathrm{a}}$ \\
\hline Heterophiles (\%) & $57.79 \pm 15.53$ & $63.42 \pm 12.49^{\mathrm{a}}$ & $52.16 \pm 17.27^{\mathrm{a}}$ \\
\hline Lymphocytes (\%) & $5.67 \pm 3.60$ & $3.64 \pm 2.05^{\mathrm{a}}$ & $8.50 \pm 3.48^{\mathrm{b}}$ \\
\hline Eosinophils (\%) & $14.20 \pm 8.82$ & $13.75 \pm 10.09^{\mathrm{a}}$ & $14.87 \pm 7.89^{\mathrm{a}}$ \\
\hline Basophils (\%) & $1.35 \pm 1.76$ & $1.50 \pm 2.12^{\mathrm{a}}$ & $1.17 \pm 1.47^{\mathrm{a}}$ \\
\hline $\begin{array}{l}\text { Monocytes } \\
\left(\times 10^{9} \mathrm{~L}^{-1}\right) \\
\text { Heterophiles }\end{array}$ & $1.31 \pm 1.03$ & $1.35 \pm 0.99^{\mathrm{a}}$ & $1.51 \pm 1.24^{\mathrm{a}}$ \\
\hline$\left(\mathrm{x} 10^{9} \mathrm{~L}^{-1}\right)$ & $8.15 \pm 4.91$ & $9.06 \pm 6.20^{\mathrm{a}}$ & $7.23 \pm 3.54^{\mathrm{a}}$ \\
\hline
\end{tabular}


Lymphocytes

$\left(\mathrm{x} 10^{9} \mathrm{~L}^{-1}\right)$

Eosinophils

$\left(\mathrm{x} 10^{9} \mathrm{~L}^{-1}\right)$

Basophils

$\left(\mathrm{x} 10^{9} \mathrm{~L}^{-1}\right)$

PCV: Packed cell volume. RBC: Red Blood Cell. Hb: Hemoglobin concentration. MCV: Mean corpuscular volume. MCHC: Mean corpuscular hemoglobin concentration. TP: Total Protein. WBC: White Blood Cell. Means with different letters presented significant difference $(P<0.05)$.

The values found for testosterone are below the sensitivity of the tests currently used in routine laboratories. Among the 12 animals, only one female presented a value above 10ng dL-1 (minimum sensitivity of the test), a value of $14.2 \mathrm{ng} \mathrm{dL}-1$. T3 values were significantly different between the sexes, being higher in males (Table 3). Two birds had above-average T3 values: one female (491 ng $\mathrm{dL}-1$ ) and one male (273ng dL-1); they also showed growth of the primary wing feathers. For T4, the aforementioned male also had elevated indexes $(4,7 \mathrm{mcg} \mathrm{dL}-1)$, but the female had an index within the mean.

Table 3 - Mean and standard deviation of the hormonal indexes between females and male Roadside hawks (Rupornis magnirostris) from seizure and assigned to the Wild Bird Rehabilitation Center (CeRAS) in João Pessoa, PB, Brazil.

\begin{tabular}{|c|c|c|}
\hline Hormones & Female & Male \\
\hline TSH (uUI mL $\left.{ }^{-1}\right)$ & $0.03 \pm 0.03^{\mathrm{a}}$ & $0.02 \pm 0.01^{\mathrm{a}}$ \\
\hline $\mathrm{T} 3\left(\mathrm{ng} \mathrm{dL}^{-1}\right)$ & $95.80 \pm 26.50^{\mathrm{a}}$ & $195.17 \pm 97.77^{b}$ \\
\hline $\mathrm{T} 4\left(\mathrm{mcg} \mathrm{dL}^{-1}\right)$ & $1,10 \pm 0.17^{\mathrm{a}}$ & $1.82 \pm 1.42^{\mathrm{a}}$ \\
\hline FSH $\left(m U I m L^{-1}\right)$ & $0.24 \pm 0.05^{\mathrm{a}}$ & $0.21 \pm 0.04^{\mathrm{a}}$ \\
\hline $\mathrm{LH}\left(\mathrm{mUI} \mathrm{mL}^{-1}\right)$ & $0.13 \pm 0.03^{a}$ & $0.13 \pm 0.08^{a}$ \\
\hline $\mathrm{E} 2\left(\mathrm{pg} \mathrm{mL} \mathrm{L}^{-1}\right)$ & $34.33 \pm 21.67^{\mathrm{a}}$ & $40.33 \pm 22.91^{\mathrm{a}}$ \\
\hline $\begin{array}{l}\text { Progesterone } \\
\left(\mathrm{ng} \mathrm{mL}^{-1}\right)\end{array}$ & $1.55 \pm 1.06^{\mathrm{a}}$ & $1.41 \pm 0.85^{\mathrm{a}}$ \\
\hline $\begin{array}{l}\text { Testosterone } \\
\left(\mathrm{ng} \mathrm{dL}^{-1}\right)\end{array}$ & $10.70 \pm 1.71^{\mathrm{a} *}$ & $10.00 \pm 0.00^{\mathrm{a} *}$ \\
\hline $\begin{array}{l}\text { TSH: Thyroid } \\
\text { Triiodothyronine. } \\
\text { Stimulating Horm } \\
\text { E2: Estradiol* Tes } \\
\text { were below the } \\
\text { laboratory test. } \\
\text { presented significa }\end{array}$ & $\begin{array}{l}\text { stimulating } \\
\text { T4: thyroxine. } \\
\text { one. LH: Luteir } \\
\text { stosterone values } \\
\text { minimum value } \\
\text { Means with } \\
\text { int difference (P }\end{array}$ & $\begin{array}{l}\text { hormone. T3: } \\
\text { FSH: Follicle } \\
\text { iizing Hormone. } \\
\text { in most animals } \\
\text { detected by the } \\
\text { different letters } \\
0.05) \text {. }\end{array}$ \\
\hline
\end{tabular}

The roadside hawks had a pair of testicles located inside the coelomic cavity, with creamy yellowish coloration, with the left testicle $(4.07 \pm 0.73 \times 2.82 \pm$
$0.18 \mathrm{~mm}$ ) slightly larger than the right one $(3.55 \pm 0.31 \times 2.70 \pm 0.14 \mathrm{~mm})$, cranially related to the adrenal glands and ventral to the kidneys (Fig. 1a).

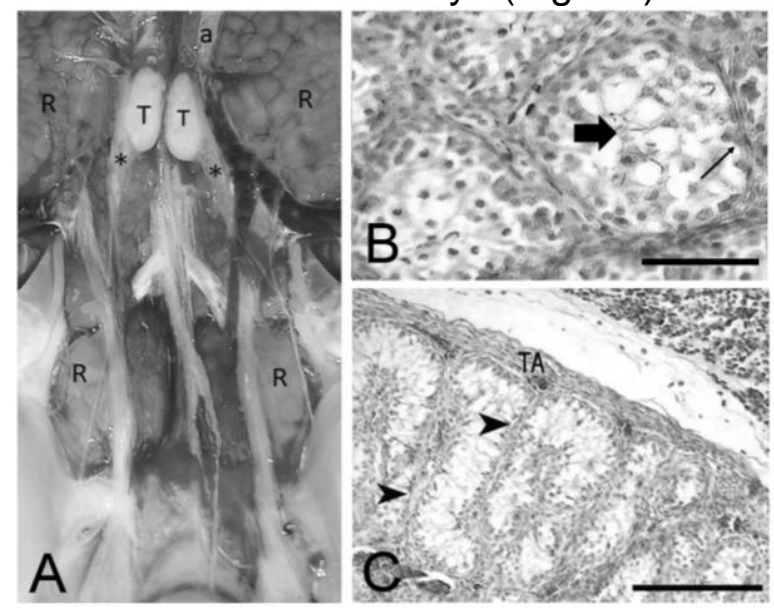

Figure 1 - Photographic image and photomicrographs of testicles of roadside hawk (Rupornis magnirostris). A) Photographic image showing the Testicles ( $T$ ), cranially related to the adrenal glands (a) and ventral to the kidneys $(\mathrm{R})$, and epididymis $\left(^{*}\right)$ emerging in the lateral regions of the testicle. B) Photomicrograph of the seminiferous tubules showing spermatozoa in the lumen of the seminiferous tubule (arrow) and Sertoli cells (arrowhead). C) Testicular photomicrography demonstrating the tunica albuginea (TA) and seminiferous tubules positioned longitudinally (arrowheads). B) Bar: $100 \mu \mathrm{m}$. C) Bar: $200 \mu \mathrm{m}$. B, C: hematoxilin-eosin stain.

The testicular parenchyma was composed of seminiferous tubules and the intertubular interstitial compartment (Fig. 1b, c); it was wrapped by the tunica albuginea (Fig. 1c). The tunic was composed of connective tissue that enveloped the testis, rich in collagen fibers, but without sending septa to the parenchyma, so it was not divided into lobes. Beneath the connective tissue there was a layer rich in blood vessels. The seminiferous tubules were irregularly enveloped, formed by the seminiferous epithelium, composed of cells of the spermatogenic lineage and support cells (Sertoli cells), and covered externally by a layer of fibroblasts that delimited the tubule. In the animals analyzed it was possible to observe the seminiferous epithelium in different phases, one which was composed only by Sertoli cells and spermatogonia (Fig. 
1c), in immature or young animals or animals that are in the early proliferation phase. In some animals, primary spermatocytes and rounded spermatids were also observed, and in one animal it was possible to verify all the phases of spermatogenesis (Fig. 1b).

In the interstitial space there were Leydig cells, fibroblast, collagen fibers and blood vessels. The interstitial or Leydig cells in the animals analyzed were difficult to visualize, generally they were found in more developed interstitial spaces and as single cells or in small groups; they had a rounded nucleus and vacuous cytoplasm.

The female roadside hawks had both ovaries. The right one was smaller than the left, and they had only the left oviduct (Fig. 2a).

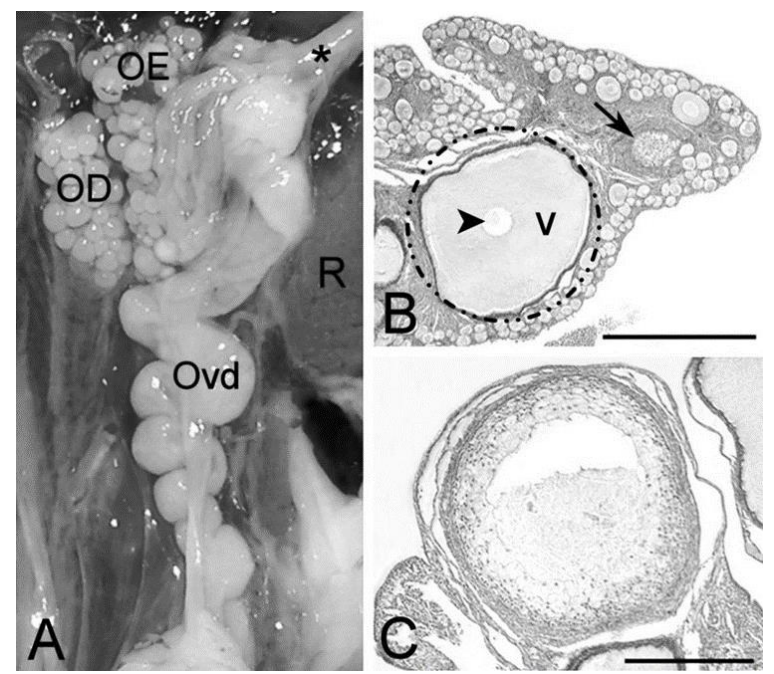

Figure 2 - Photographic image and photomicrographs of the female reproductive system of the roadside hawk (Rupornismagnirostris). A) Photographic image of the Left Ovary (OE), Right Ovary (OD), Cranial ligament of infundibulum $\left({ }^{*}\right)$ and kidney (R). B) Photomicrograph of ovary demonstrating follicles at various stages of development, vitellogenic follicle (traced), follicular vitellius (V) and its nucleus (arrowhead) and post-ovulatory follicle (arrow). C) Photomicrograph of post-ovulatory follicle. B) Bar: 800 $\mu \mathrm{m}$. C) Bar: $300 \mu \mathrm{m}$. B, C: hematoxilin-eosin stain.

The ovaries were formed by the cortex and the medulla; the cortex consisted of stroma, blood vessels and follicles at various stages of development. In this species, it was also possible to observe the presence of post-ovulatory follicles, also called vacuolar cells (Fig. 2b, c). In this species it was also possible to observe the presence of post-ovulatory follicles, also called vacuolar cells that had a cytoplasm rich in lipids that gives it a vascular aspect and pyknotic nucleus.

\section{DISCUSSION}

This is one of the most complete studies on the species $R$. magnirostris, with the hematological, hormonal and morphological parameters of the gonads of the species, a comparison between the hematology of specimens and the high degree of stress of the specimens already in captivity for more than one year. It also draws a hormonal comparison between the males and females.

Regarding weight, the average value for the species in the region $(267 \mathrm{~g})$ is in line with the average described by other authors, which is of 206-350g (Márquez et al., 2005) or 250 to $300 \mathrm{~g}$ (Sick, 1997). Although there are no differences in the weights of the animals in the two groups studied, the recently captured birds and those that had been in captivity for at least one year, it is possible to observe differences in their hematological parameters (erythrocytes, PCV and lymphocytes). The most probable causes for these alterations are the stress of captivity and differentiated feeding (Martinez-Silvestre et al., 2011; Silva et al., 2009). The stimulation of the adrenocortical due to stress causes hematological alterations, as already demonstrated in some specific species. In chickens, for example, administration of corticosterone, a hormone related to stress, results in leukocytosis, heterophilia and lymphopenia (Davison and Flack, 1981; Post et al., 2003). Under stress conditions, blue macaws (Anodorhynchus hyacinthinus) had heterophilia and lymphopenia (Speer and Kass, 1995), and Harris' hawks 
(Parabuteo unicictus) have lymphopenia after a transportation episode under stress conditions (Parga et al., 2001). In contrast, in domestic pigeons (Columbia livia) and cattle egrets (Bubulcus ibis), have heteropenia and lymphocytosis as a response (Bhattacharyya and Sarkar, 1968). In this study, the birds in group 1 , which had been in captivity for less time, probably had greater stress due to the movement of the public in the zoo and captivity conditions, and therefore, it is possible to observe lymphopenia in these animals. This finding corroborates the experiment in which corticosterone was administered to chickens (Davison and Flack, 1981; Post et al., 2003), and the studies on blue macaws and Harris' hawks under stress (Speer and Kass, 1995; Parga et al., 2001).

Another parameter to evaluate the stress response in birds is the ratio between H:L (heterophile: lymphocyte), which is more sensitive in birds (Post et al., 2003). In our study, the ratio was 17:1 for group 1 and 6:1 for group 2, demonstrating that the recently-arrived birds had less adaptation to captivity, therefore they were more stressed by the presence of the public and space restriction. The alteration in this ratio was also found in peregrine falcons (Falco peregrinus) and Harris' hawks (Parabuteo unicinctis) submitted to transportation stress (Parga et al., 2001).

The values of globular volume and erythrocyte counts were significantly different when comparing the two groups, and were higher in the animals with shorter time in captivity. This difference in the erythrogram has not been reported in wild birds, and it has been suggested that the homeostasis process is a direct product of the complex and dynamic interrelations between host and environment. When this balance is altered it may reflect directly on hematological parameters
(Thralli et al., 2012). In addition, another possible reason for erythrocyte growth is splenic contraction during physical restraint, which can lead to the release of more erythrocytes into the circulation. Since the animals that have been in the zoo for more time have already undergone more management episodes, they are more adapted to manipulation (Almeida et al., 2011). Since several factors can influence reference values for healthy birds, including age, season, and sex, studies in several conditions are important to clarify peculiarities of the species (Black et al., 2011). In this study, less stressful (animals in captivity for a longer time) and more stressful (recently captured animals) situations were mimicked.

In relation to the hormonal studies for $R$. magnirostris, among genders, only T3 was different, and was much higher in the males. One male and one female that had the highest T3 indexes had growth of primary feathers on the wings. In the male there was also an increase in T4. The increase of the thyroid hormones causes the increase of the oxygen consumption, functioning as modulators of the basal metabolic rate (Welcker et al., 2013). Therefore, they are considered the most important in the control of the metabolic processes of birds by influencing various physiological processes, such as: growth of different body structures, synthesis and metabolism of proteins, carbohydrates and lipids, thermogenesis, and body composition, even acting on moulting of feathers (Rosebrough, 1999), which was evidenced by the increase of T3 during the growth of the birds' primary feathers in the aforementioned individuals.

Meticulous control of feathering is necessary because most birds depend on them for flight, cutting and thermoregulation, and since this is a physiological process that requires a lot of energy, it must be precisely controlled 
so that it occurs at the correct time of the year and symmetrically in birds that fly (Meier and Ferrell, 2010). Turkeys also show an increase of T3 during feathering, reaching a peak at the end of this stage (Lien and Siopes, 1993). Domestic geese also show increased T3 during moulting, however, T4 levels remain low (Péczel et al., 2011). Due to seasonal variation, it is also necessary to standardize the hormonal parameters during the different annual cycles so that it is possible to use them reliably (Merryman and Buckles, 1998).

$$
\text { According to gonadal }
$$

morphological analyses, the (two) roadside hawk testicles were within the celomatic cavity and had a small asymmetry; the left testicle was larger, as is found in emus, quails and whiteeyed parakeets (Psittacara leucophthalmus) (Santos et al., 2011; Lanna et al., 2013; Peixoto 2006). In relation to number, in literature, only the African black cuckoo (Centropus grillii) is reported to have only one testicle, and the vestigial testicle is on the left (Frey and Goymann, 2009). The arrangement and location of the gonads in this bird is similar to that in other birds (Santos et al., 2011; Matsumoto et al., 2009).

Among the individuals studied, it was possible to observe different conformations in the seminiferous epithelium. This fact indicates that the species has seasonal reproduction, as well as domestic quails, white-eyed parakeets (Psittacara leucophthalmus), American Kestrel (Falcos parverius) and sparrows (Passer montanus) (Amoroso et al., 2008; Dixit and Singh, 2013; Peixoto, 2006). Santos and Rosado (2009) when studying the biological characteristics of the roadside hawks in southern Brazil, observed that the beginning of the reproductive period occurs in August with the behavior of cutting and building nests. The birds in this present study were collected and analyzed between June and July 2015, and in only one of the 6 male animals it was possible to observe all phases of spermatogenesis; the others had characteristics of seminiferous epithelium of resting phase, that is, with only spermatogonia and Sertoli cells, or at the beginning of the proliferation phase, with the appearance of primary spermatocytes. During the reproductive stage in males, an increase in the size of the testicles occurs due to the increase in the size of the seminiferous tubules and the number of interstitial cells. During this period, the weight of the testis represents approximately $1 \%$ of the weight of the bird (Santos et al., 2011; Tully et al., 2011) and this increase may vary from 10 to $500 \%$ when compared to the size in the nonreproductive phase in which the testes atrophy and become similar to the juvenile testicles (Madekurozwa et al., 2002; Santos et al., 2011; Tully et al., 2011). These reports are in agreement with our findings since the bird that showed all phases of spermatogenesis had larger testicle than the others.

These findings demonstrate that even in northeastern Brazil, where the seasons are not accentuated, this species has reproductive seasonality. Hau (2001), when studying spotted antbird (Hylophylax naevioides) in a tropical region, and small ground finches (Geospiza fuliginosae) in the arid Galapagos Islands, proposed that reproductive seasonality can be controlled by several factors, including the presence of rain and abundance of food. It also describes that despite the small annual variation in photoperiodism in the tropical region, local birds can measure this tiny increase in photoperiod, which is a trigger for the beginning of the reproductive phase. This probably also occurs with the roadside hawk in northeastern Brazil.

The roadside hawk females, unlike most birds, had persistence of both ovaries in 4 out of 6 birds, but with 
a smaller right ovary, and only the left oviduct present, which is consistent with other birds of prey and American Kestrel (Tully et al. 2011). Similar percentages are observed in 3 species of buteos (60 - 75\%) (Chappellier 1914, Stanley and Witschi, 1940). In two-week-old emus, it is still possible to observe the presence of both ovaries, however, after maturation, the right one becomes an amorphous mass (Parizzi et al. 2007).

In the histological analysis, ovarian follicles were observed in different phases, classified as immature (or primordial), pre-vitellogenic (or primary) and vitellogenic (or secondary). In the analyzed females, no mature (or pre-ovulatory) follicles were found, probably due to the reproductive seasonality of the species (Dixit and Singh 2013). It can be emphasized that the two ovaries had vitellogenic follicles, assuming that the two ovaries are functional. Rodler et al. (2015) used immunohistochemistry and found that the right ovary of birds of prey shows structures of the cytoskeleton (tubulin and vimentin) and a-activin of smooth muscle, with positivity only slightly weaker when compared to the left ovary, but with normal estrogen and progesterone receptors, which demonstrates the potential of folliculogenesis and ovulation in both ovaries.

Post-ovulatory follicles, which produce progesterone for a short time until ovulation occurs and then are reabsorbed, were also found in the specimens studied (Ito et al., 2011). In female ducks, its reabsorption occurs on average in a week, and thereafter is no longer visible to the naked eye Davis (1942). Hodges (1974) describes 4-5 of these follicles in sexually active adult chickens. The function of these structures has been questioned for years, since there is no structure analogous to the corpus luteum which occurs in mammals, because there is no gestation. However, in birds there is a gland that hosts sperm, located at the junction of the uterus and the vagina, which has the function of storing the spermatozoa until the time of fertilization (Bacha and Bacha, 2003). Ito et al. (2011) demonstrated that in birds, progesterone has a function of releasing these sperms so that fertilization occurs at the correct time. In laying hens, this release by the post-ovulatory follicle occurs 20 hours after ovulation.

This is the first study to present the hematological, hormonal and gonadal morphological profile, in addition to comparing hematology in specimens with different levels of stress, and to demonstrate the hormonal variation between roadside hawk genera, which is the bird of prey species reported as the most frequent in screening and rehabilitation centers, and in anthropogenic environments (Santos et al., 2015). Studies such as these serve as subsidies for better compression of the health and reproduction of birds of prey, and such measures are foreseen in the national action plan for the conservation of birds of prey of the ICMBio (Soares et al. 2008). Due to efforts to conserve birds of prey in the last three decades and due to anthropic actions on their habitat, more of these birds have been brought to veterinarians (Tully et al., 2011), making reference values necessary for these species. These values and the morphological description of the gonads of the species can serve as subsidies for clinical, nutritional and reproductive management. Within this context, the roadside hawk can even be a model species, thus favoring not only its studies but also of other falconiformes. 


\section{CONCLUSION}

We concluded that there is an alteration in the hematological profile of roadside hawks under captivity stress and management. The reproductive and stress hormonal parameters of this species were performed for the first time and showed interaction with the moulting of feathers. In addition to the above, the species demonstrated persistence of two ovaries in most of the specimens and other characteristics indicative of a seasonal reproductive cycle in the Brazilian Northeast.

\section{REFERENCES}

ALMEIDA, A.M.; NOGUEIRA-FILHO, S.L.; NOGUEIRA, S.S. et al. Aspectos hematológicos de catetos (Tayassu tajacu) mantidos em cativeiro. Pesquisa Veterinária Brasileira, v. 31, p.173-177, 2011.

ALMOSNY, N.R.P.; MONTEIRO, A.O. Patologia clínica. Rio de Janeiro: Roca, 2007. 966 p.

AMOROSO, L.; ARTONI, S.M.B.; MORAES, V.M.B.D. et al. Influência da espermatogênese e dos níveis de testosterona no aspecto reprodutivo de codornas. Revista Brasileira de Zootecnia, v.37, p.61-66, 2008.

BACHA, W.J.; BACHA, L.M. Atlas colorido de histologia veterinária. Rio de Janeiro: Roca, 2003. 247 p.

BARALDI-ARTONI, S.M.; BOTTINO, F.; OLIVEIRA, D. et al. Morphometric study of Rynchotus rufescens testis throughout the year. Brazilian Journal of Biology, v.67, p.363-367, 2007.

BERCOVITZ, A.B.; COLLINS, J.; PRINCE, $P$. et al. Noninvasive assessment of seasonal hormone profile in captive bald eagles (Haliaeetus leucocephalus). Zoo Biology, v.1, p.111-117, 1982.

BHATTACHARYYA, T.K.; SARKAR, A.K. Avian leucocytic responses induced by stress and corticoid inhibitors. Indian Journal of Experimental Biology, v.6, p.26, 1968.

BLACK, P.A.; MCRUER, D.L.; HORNE, L.A. Hematologic parameters in raptor species in a rehabilitation setting before release. Journal of Avian Medicine Surgery, v.25, p.192 - 198, 2011.

CARVALHO, C.C.; RAMOS, J.A.; RAMEH-DE-ALBUQUERQUE, L.C. et al. Blood profile, serum biochemistry, Creactive protein and cortisol in golden conures (Guaroba guarouba) in captivity. Pesquisa Veterinária Brasileira, v.33, v.394-398, 2013.

CBRO - Comitê Brasileiro de Registros Ornitológicos. Listas das aves do Brasil. 2011. Eletronic resource. < http://www.taxeus.com.br/listamaisinfor macoes/12>. (accessed June 2016).

CHAPPELLIER, A. Persistance et developpement des Organes Géniteaux Droit chex les Femelles Adultes des Oiseaux. Bull Sci Fr Belg, v.47, p.361376, 1914.

DAVIS, D.E. The regression of the avian post-ovulatory follicle. Anatomical Record, v.8, p.297-307, 1942.

DAVISON, T.F., FLACK, I.H. Changes in the peripheral blood leucocyte populations following an injection of corticotrophin in the immature chicken. Research Veterinary and Science, v.30, p.79, 1981.

DIXIT, A.S.A.N.D.; SINGH, N.S. Environmental control of seasonal reproduction in the wild and captive Eurasian Tree Sparrow (Passer 
montanus) with respect to variations in gonadal mass, histology, and sex steroids. Canadian Journal of Zoology, v.91, p.302-312, 2013.

]

FERGUSON-LEES, J.; CHRISTIE, D.A. Raptors of the world. Boston: Houghton Mifflin Harcourt, 2001. 992 p.

FREY, R.; GOYMANN, W. A single functional testis and long deferent duct papillae: the peculiar male reproductive tract of the classically polyandrous, sexrole reversed Black Coucal (Centropus grillii). Journal of Ornithology, v.150, n.4, p.827-838, 2009.

HAU, M. Timing of breeding in variable environments: tropical birds as model systems. Hormony and Behavior, v.40, p.281-290, 2001.

HODGES, R.D. The histology of the fowl. Academic Press, 1974.

ITO, T.; YOSHIZAKI., N.; TOKUMOTO., T. Progesterone is a sperm-releasing factor from the sperm-storage tubules in birds. Endocrinology, v.152, p.39523962, 2011.

LANNA, L.L.; SOARES, F.A.; SANTOS, T.MÍndice gonadossomático e correlações entre dimensões e peso testiculares na codorna japonesa (Coturnix coturnix japonica) aos 60 dias de idade. Arquivo Brasileiro de Medicina Veterinária e Zootecnia, v.65, p.955-960, 2013.

LERNER, H.R.; KLAVER, M.C.; MINDELLI, D.P. Molecular phylogenetics of the Buteonine birds of prey (Accipitridae). The Auk, v.125, p.304315, 2008.

LIEN, R.J.; SIOPES, T.D. The relationship of plasma thyroid hormone and prolactin concentrations to egg laying, incubation behavior, and molting by female turkeys exposed to a one-year natural daylength cycle. Gen Comp Endocrinol, v.90, p.205-213, 1993.

MADEKUROZWA, M.C.; CHABVEPI, T.S.; MATEMA, S. et al. Relationship between seasonal changes in spermatogenesis in the juvenile ostrich (Stuthio camelus) and the presence of the LH receptor and 3betahydroxysteroid dehydrogenase.

Reproduction, v.123, p.735-742, 2002. MÁRQUEZ, C.; BECHARD, M.; GAST, $F$. et al. Aves Rapaces Diurnas de Colombia. Instituto de investigaciones de Recursos Bióticos "Alexander von Humboldt", 2005. 394 p.

MARTÍNEZ-SILVESTRE, A.; LAVÍN, S.; CUENCA VALERA, R. Hematología y citología sanguínea en reptiles. In Clínica veterinaria de pequeños animales: revista oficial de AVEPA, Asociación Veterinaria Española de Especialistas en Pequeños Animales, v.31, p.131-141, 2011.

MATSUMOTO, F.S.; CARVALHO, A.F.; FFRANCIOLLI, A.L.R. et al. Topografia e morfologia das vísceras do PeriquitoAustraliano (Melopsittacus undulatus, SHAW 1805). Ciência Animal Brasileira, v.10, p.1263-1270, 2009.

MEIER, A.H.; FERRELL, B.R. Avian endocrinology. Chemical Zoology, v.10, p.213-271, 2010.

MERRYMAN, J.I.; BUCKLES, E.L. The avian thyroid gland. Part two: a review of function and pathophysiology. Journal of Avian Medicine and Surgery, v.12, p.238-242, 1998.

PARGA, M.L.; PENDL, H.; FORBES, N.A. The effect of transport on hematologic parameters in trained and untrained Harris's hawks (Parabuteo 
unicinctus) and peregrine falcons ( $\mathrm{Falco}$ peregrinus). Journal of Avian Medicine and Surgery, v.15, p.162-169. 2001.

PARIZZI, R.C.; MIGLINO, M.A.; MAIA, M.O. et al. Morfologia do ovário da ema (Rhea americana). Pesquisa Veterinária Brasileira, v.27, p.89-94, 2007.

PÉCZELY, P.; BOGENFURST, F.; KULCSAR, M. et al. Role of gonadal and adrenal steroids and thyroid hormones in the regulation of molting in domestic goose. Acta Biol Hung, v.62, p.1-21, 2011.

PEIXOTO, J.V. Avaliação morfofuncional do testículo e do processo espermatogênico do periquitão-maracanã

(Aratinga leucophthalma MULLER, 1776) adulto, mantido em cativeiro, nas diferentes estações do ano. Viçosa: UFV, 2006.

PEREIRA, R.J.G.; GRANZINOLLI, M.A.M.; DUARTE, J.M.B. Annual profile of fecal androgen and glucocorticoid levels in free-living male American kestrels from southern mid-latitude areas. Gen Comp Endocrinol, v.166, p.94-103, 2010.

POST, J.; REBEL, J.M.; HUURNE, A.A. Automated blood cell count: a sensitive and reliable method to study corticosterone-related stress in broilers. Poultry Science, v.82, p.591-595, 2003.

RAMOS, A.H.; SANTOS, L.M.; MIGLINO, M.A. et al. Biometria, histologia e morfometria do sistema digestório do cachorro-do-mato (Cerdocyon thous) de vida livre. Biotemas, v.24, p.111-119, 2011.

RODLER, D.; STEIN, K.; KORBEL, R. Observations on the Right Ovary of Birds of Prey: A Histological and
Immunohistochemical Study. Anatomia, Histologia, Embryologia, v.44, p.168177, 2015.

ROSEBROUGH, R.W.; MCMURTRY, J.P.; VASILATOS-YOUNKEN, R. Dietary fat and triiodothyronine (T3) interactions in the broiler chicken. International Journal of Vitamine and Nutrition Research, v.69, p.292-298, 1999.

SANTOS, J.T.; DIAS, G.F.; CARVALHO, $T$. et al. Reabilitação e soltura de aves de rapina efetuada pelo centro de reabilitação de aves silvestres (CeRAS) em João Pessoa, Paraíba. Anais do congresso da SZB, 2015.

SANTOS, T.C.; SOUSA, J.A.; OLIVEIRA, M.F. et al. Morphology of the male genital organs and cloaca of Rhea americana americana. Pesquisa Veterinária Brasileira, v.31, p.430-440, 2011.

SANTOS, W.M.; ROSADO, F.R. Dados preliminares da biologia do gavião-carijó (Rupornis magnirostris, Gmelin, 1788) na região Noroeste do Paraná. Revista em Agronegócio e Meio Ambiente, v.2, p.421-430, 2009.

SICK, H. Ornitologia brasileira. Rio de Janeiro: Nova Fronteira, 1997.

SILVA PH, HASHIMOTO Y, ALVES HB. Hematologia laboratorial. Rio de Janeiro: Revinter, 2009. 466 p.

SOARES, E.S.; AMARAL, F.S.R.; CARVALHO FILHO, E.P.M. et al. Plano de ação nacional para a conservação de aves de rapina. Instituto Chico Mendes de Conservação da Biodiversidade, Série Espécies Ameaçadas. Brasília. < http://www.icmbio.gov.br/portal/images/s tories/docs-plano-de-

acao/panaverapina.pdf> (accessed July 2016). 2008. 
SPEER, B.L.; KASS, P.H. The influence of travel on hematologic parameters in hyacinth macaws. Association of Avian Veterinarians, v.2, p.43-49, 1995.

STANLEY, A.J. WITSCHI, E. Germ cell migration in relation to asymmetry in the sex glands of hawks. The Anatomical Record, 76, p.329-342, 1940.

THRALL, M.A.; WEISER, G.; ALLISON, $R$. et al. Veterinary hematology and clinical chemistry. Hoboken: John Wiley \& Sons, 2012.

TULLY T, DORRESTEIN GM, JONES A. 2011. Clínica de aves. 2st ed. Elsevier, Brasil.

WELCKER, J.; CHASTEL, O.; GABRIELSEN, G.W. et al. Thyroid hormones correlate with basal metabolic rate but not field metabolic rate in a wild bird species. PloS one, 8: e56229, 2013. 